\title{
Contents, Volume 16 (2005)
}

Alipanah, H. \& Ustjuzhanin, P.: An annotated list of the Pterophorinae (Oidaematophorini and Pterophorini) of Iran (Lepidoptera: Pterophoridae)..................129-143

An, S. \& Yang, D.: Review of the genus Meromyza from China (Diptera: Chloropidae) ... 151

Aslan, I. \& Warchalowski, A.: Longitarsus ozbeki sp. n., a new species from Asia Minor (Coleoptera: Chrysomelidae: Alticinae)...................................... 221-224

Baran, T. \& Buszko, J.: Elachista baltica Hering, 1891 sp. rev. - a valid species of Elachistidae from the Baltic shore (Lepidoptera: Gelechioidea)......................9-18

Barkalov, A. V.\& Stíhls, G.: On the status of species of the genus Cheilosia Mg. (Diptera: Syrphidae) described by Hervé-Bazin.. 183-192

Bengtsson, B. Å.: Notes on Palaearctic scythridids with description of nine new species (Lepidoptera: Scythrididae)

207-220

Buhl, P. N.: New or little known Palaearctic species of Platygastrinae (Hymenoptera: Platygastridae). II.

Ćurčić, B. P. M. Ćurčić, L. R. Ćurčić, S. B. \& Ćurčić, N. B.: Hymenaphorura uzicensis, a new cave species of springtails (Collembola: Onychiuridae from West Serbia...

175-178

Ćurčić, S. B., Ćurčić, B. P. M., Makarov, S. E., Mitić, B. M. \& Mihajlova, B.: On three new high-altitude endemic leiodids (Coleoptera: Leiodidae) from the Balkan Peninsula...... 309-316

Czechowski, W., Czechowska, W. \& Vepsäläinen, K.: Structure and succession of Lasius s. str. (Hymenoptera: Formicidae) assemblages in a Finnish sand dune area - reassessment after taxonomic revisions of the subgenus ..... 2-8

Durska, E., Kaczorowska, E. \& Disney, R. H. L.: Scuttle flies (Diptera: Phoridae) of saline habitats of the Gulf of Gdańsk, Poland

159-164

Kettunen, J., Kobro, S. \& Martikainen, P.: Thrips (Thysanoptera) from dead aspen (Populus tremula) trees in Eastern Finland 246-250

Koç, H. \& Oosterbroek, P.: A new species of Tipula (Lunatipula) from Turkey, close to T. (L.) imbecilla Loew (Diptera: Tipulidae)..... 19-22

Koç, H., Oosterbroek, P. \& Özgül, O.: A new Turkish Tipula (Lunatipula) species in the acuminata group (Diptera: Tipulidae)

251-253

Konvicka, M., Hula, V. \& Fric, Z.: Picromerus bidens (Heteroptera: Pentatomidae) as predator of the Checkerspot Euphydryas aurinia (Lepidoptera: Nymphalidae) ........................................... 233-236

Koponen, M. \& Vikberg, V.: Phaenocarpa hirsuta sp. n., $P$. picinervis (Haliday) and $P$. angustiptera Papp new to the fauna of Finland (Hymenoptera: Braconidae:
Alysiinae).

$51-60$

Montasser, A. \& Amin, A.: Fine structure of the integument of Argas (Persicargas) persicus (Oken) (Ixodoidea: Argasidae) 193-200

Nupponen, K., Jürivete, U. \& Pototski, A.: Records of scythridids from Southeastern Kazakhstan, with description of five new species (Lepidoptera: Scythrididae)

65-73

Nupponen, K.: Notes on Palaearctic Scythrididae, with description of two new species (Lepidoptera: Scythrididae) 165-174

Nupponen, K.: The description of Scythris arenicola sp. n. from the Southern Ural Mountains (Lepidoptera: Scythrididae) ...... 179-182

Polidori, C., Disney, R. H. L., Boesi, R. \& Andrietti, F.: Association of the scuttle fly Megaselia leucozona Schmitz (Diptera: Phoridae) with sweat bees (Hymenoptera: Halictidae), with a description of the male fly 144-158

Prescher, S., Bonet, J. \& von Tschirnhaus, M.: New records of scuttle flies (Diptera: Phoridae) from Iceland, with a survey of all simultaneously collected Dipteran families........................................................... 237-245

Salmela, J. \& Vilkamaa, P.: Sciaridae (Diptera) from central Finland: faunistics and taxonomy .............287-300

Salmela, J. \& Piirainen, T.: Description of a new Psychodidae (Diptera) species from Estonia ...............301-304

Shah, Z. A. \& Shahzad, M. K.: Fluctuation patterns of different developmental stages of Helicoverpa armigera (Lepidoptera: Noctuidae) on chickpea (Cicer arietinum) and their relationship with the environment 201-206

Sugisima, K. \& Kaila, L.: Japanese Elachista mining on the leaf of woody Poaceae (Lepidoptera: Elachistidae $s$. str.)......................................................... 83-102

Tóth, P., Cristofaro, M. \& Cagáň, Ĺ.: Seasonal biology of Melanagromyza albocilia (Diptera: Agromyzidae) and seasonal patterns of field bindweed infestation, under field conditions in Slovakia...........................254-262

Tóthová, A., Knoz, J., Barták, M. \& Kubík, Š.: Biomonitoring of Ceratopogonidae (Diptera: Nematocera) using car nets 124-128

Vikberg, V. \& Koponen, M.: Contribution to the taxonomy of the Palaearctic species of the genus Laelius Ashmead, mainly from Finland and Sweden (Hymenoptera: Chrysidoidea: Bethylidae) ...........................23-50

Välimäki, P. \& Itämies, J.: Effects of canopy coverage on the immature stages of the Clouded Apollo butterfly [Parnassius mnemosyne (L.)] with observations on larval behaviour. $117-123$

Wang, X. \& Li, H.: A new genus and species of Tortricinae (Lepidoptera: Tortricidae) from China .263-265 
Wang, M. \& Yang, D.: Two new species of the genus Nepalomyia, with a key to species from China (Diptera: Dolichopodidae) 103-108

Wiklund, C.: Hornet predation on peacock butterflies and ecological aspects on the evolution of complex eyespots on butterfly wings. 266-272

Wu, Q. \& Chen, X.: Four new species of the genus Eurytenes Foerster (Hymenoptera: Braconidae: Opiinae) from China 225-232

Xue, H. \& Bu, W.: Notes on $5^{\text {th }}$ instar nymphs of two species of Phaenacantha Horv h (Heteroptera: Colobathristidae) 109-116

Zhang, L. \& Yang, D.: A new species of Ludovicius from China (Diptera: Dolichopodidae). 305-308

Zhang, A., Li, H. \& Wang, S.: Study on the genus Rhopobota Lederer from China (Lepidoptera: Tortricidae: Olethreutinae)

\section{Book reviews}

Silfverberg, H.: Catalogue of Ceutorhynchinae of the World, with a key to Genera 317

Tammaru, T.: The Geometrid Moths of Europe, Vol. 2: Sterrhinae. 318

Itämies, J.: Die Larven der Europäeischen Noctuidae. Revision der Systematik der Noctuidae (Larvae of European Noctuidae. Revision of the systematics of the Noctuidae) 319

\section{Other}

Koivula, M.: New Editor-in-chief for Entomologica Fennica ................................................................. 1 Silfverberg, H.: Martin Meinander 1940-2004 ..........61-64 